\title{
Pemberdayaan UMKM Kampung Pia Melalui Sistem Akuntansi dan Strategi Pemasaran
}

\author{
Ahmad Mukoffi ${ }^{1 *}$, Sukarno Himawan Wibisono ${ }^{2}$, Hermi Sularsih ${ }^{3}$, As'adi $^{4}$ \\ ${ }^{1,2}$ Program Studi Akuntansi, Universitas Tribhuwana Tunggadewi, Jl. Telaga Warna, Tlogomas \\ Malang \\ ${ }^{3,4}$ Program Studi Akuntansi, Sekolah Tinggi Ilmu Ekonomi Gempol, Jl. Raya Timur Pasar No. 09 \\ Gempol, Pasuruan
}

\begin{tabular}{|l|l|l|l|}
\hline Diterima: $20-12-2021$ & Direvisi: 26-12-2021 & Disetujui: 28-00-2021 & Dipublikasi: 31-12-2021 \\
\hline
\end{tabular}

\begin{abstract}
The low level of education owned by business owners has an impact on the lack of knowledge and understanding of the applicable accounting system, especially SAK EMKM for MSMEs. This causes the preparation of financial reports according to standards that have an impact on the difficulty of MSMEs in measuring the amount of operational costs incurred and the amount of income received. The lack of ability of MSMEs in determining the right marketing strategy is a problem that occurs in MSMEs. Through training in accounting systems and marketing strategies, they can provide knowledge and understanding for the empowerment of MSMEs. Through the empowerment of MSMEs, it is expected to be able to develop businesses.
\end{abstract}

Keywords: SAK EMKM, Marketing Strategy, MSMEs

\begin{abstract}
Abstrak
Rendahnya tingkat pendidikan yang dimiliki pemilik usaha berdampak pada kurangnya pengetahuan dan pemahaman terhadap sistem akuntansi yang berlaku khususnya SAK EMKM bagi UMKM. Hal ini menyebabkan kurang tepatnya penyusunan laporan keuangan sesuai standar yang berdampak pada sulitnya UMKM dalam mengukur jumlah biaya operasional yang dikeluarkan dan jumlah pendapatan yang diterima. Minimnya kemampuan UMKM dalam menentukan strategi pemasaran yang tepat merupakan permasalahan yang terjadi pada UMKM. Melalui pelatihan sistem akuntansi dan strategi pemasaran dapat memberikan pengetahuan dan pemahaman untuk pemberdayaan UMKM. Melalui pemberdayaan UMKM diharapkan dapat mengembangkan usaha.
\end{abstract}

Kata kunci: SAK EMKM, Strategi Pemasaran, UMKM.

\section{Pendahuluan}

Pemberdayaan masyarakat adalah konsep pembangunan ekonomi yang bersifat people centered, empowering, dan sustainable (Saputro \& Susilo, 2016). Salah satu upaya pemberdayaan masyarakat yang dapat dilakukan oleh pemerintah adalah dengan mengembangkan dan mendukung masyarakat terlibat dalam usaha mikro, kecil, dan menengah (UMKM). UMKM merupakan usaha yang memberikan kontribusi dalam perkembangan ekonomi di Indonesia karena sektor UMKM terbukti dapat menyerap tenaga kerja dan peningkatan pendapatan masyarakat (Sandhana, 2013). UMKM juga berperan meningkatkan taraf hidup dan membuka lapangan kerja baru bagi masyarakat pada umumnya.

\footnotetext{
* Penulis korespondensi

Email: unitriahmadmukoffi@gmail.com
} 
Gempol merupakan kota dengan jajanan khas yang dikenal banyak masyarakat salah satunya adalah pia, tepatnya di Dusun Warurejo Gempol, Pasuruan yang diberi nama "KAMPUNG PIA". Di sini terdapat banyak industri rumahan pia yang pada awalnya merupakan paguyuban yang anggotanya 20 orang, kemudian menjadi 48 orang, dan bertambah lagi menjadi 52 orang, hingga sekarang anggota tetap paguyuban ini menjadi 50 orang. Dalam paguyuban ini semua anggota memiliki tujuan yang sama yaitu mengembangkan keanggotaan dan semua berkontribusi untuk kemajuan Kampung Pia. Bapak Alfan merupakan salah satu pemilik usaha pia yang dirintisnya sejak tahun 2012 dan diberi nama "PIA AQILA". Awal mulanya, ada pesanan 950 kotak pia dari orang pengajian dari Surabaya yang rombongan mobilnya tepat berhenti di depan rumah Bapak Alfan. Melalui berita dari mulut ke mulut, "PIA AQILA" ini mulai dikenal banyak masyarakat khususnya sebagian dari kota Surabaya, Sidoarjo, dan Malang. Selain itu pemasaran juga dilakukan di Pasar Pandaan sebelah Masjid Cheng Ho dan Pasar Lawang. Omzet dari penjualan di kedua tempat tersebut kurang lebih Rp1.750.000,00 dan pesanan terjual 200 kotak per harinya. "PIA AQILA" berbeda dengan yang lain karena Bapak Alfan menggunakan minyak merk Sunco untuk mengolesi tepung dengan alasan bahwa hasil dari produksi pia dengan minyak ini tetap gurih dan empuk dalam beberapa hari. Bapak Alfan tidak mencampurkan bahan pengawet dalam proses produksi sehingga pia Bapak Alfan hanya bertahan 5 hari, dan alat yang digunakan masih tradisional.

Permintaan pia terus meningkat dan membuka peluang pasar bagi pengusaha untuk meningkatkan jumlah produksi pia. Peningkatan pada permintaan "PIA AQILA" harus terus dijaga agar pendapatan semakin meningkat. Meskipun begitu, peningkatan permintaan pasar tidak dapat dijadikan jaminan umur panjang bagi perusahaan. Ancaman datang dari banyaknya perusahaan pia lain yang berdiri. Untuk itu, perlu strategi pemasaran yang tepat dalam mengembangkan usaha dengan meningkatkan jumlah pendapatan. Permasalahan lainnya pada UMKM PIA adalah ketidakpahaman akan pencatatan akuntansi sesuai dengan SAK EMKM. SAK EMKM disusun untuk memenuhi kebutuhan pelaporan keuangan entitas mikro, kecil dan menengah. SAK EMKM ditujukan untuk digunakan oleh entitas yang tidak atau belum mampu memenuhi persyaratan akuntansi yang diatur SAK ETAP (Ikatan Akuntansi Indonesia, 2016). SAK EMKM diharapkan dapat membantu sekitar 62,9 juta pelaku UMKM di Indonesia dalam menyusun laporan keuangannya dengan tepat tanpa harus terjebak dalam kerumitan standar akuntansi keuangan yang ada saat ini. SAK EMKM ini merupakan standar akuntansi keuangan yang lebih mudah untuk digunakan oleh para pelaku UMKM karena jauh lebih sederhana dibandingkan SAK ETAP. Pada pencatatan akuntansi, UMKM juga tidak memahami siklus pengeluaran yang tepat sehingga tidak dapat mengetahui komponen-komponen apa saja yang menentukan jumlah pengeluaran. Karena siklus pengeluaran merupakan serangkaian aktivitas bisnis dan kegiatan pengolahan data yang berhubungan dengan pembelian dan pembayaran atas barang dan jasa yang dibeli. Untuk itu penting pemahaman bagi UMKM terhadap siklus pengeluaran yang berkaitan dengan perkembangan usaha.

\section{Metode Pengabdian}

Kegiatan pengabdian ini dilaksanakan untuk memberikan solusi dalam pencatatan akuntansi sesuai SAK EMKM dan strategi pemasaran yang tepat dalam mengembangkan usaha. Metode pelaksanaan pengabdian dilaksanakan berdasarkan tahapan-tahapan berikut. 


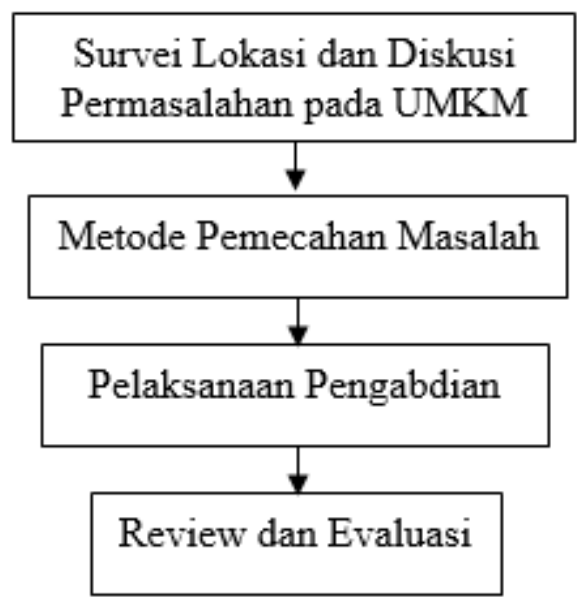

Gambar 1. Tahapan-Tahapan Kegiatan

1. Survei Lokasi dan Diskusi Permasalahan pada UMKM

Survei lokasi dan diskusi dilakukan untuk pengamatan dan dialog dengan pemilik usaha guna mengetahui permasalahan yang terjadi pada UMKM dalam mengelola laporan keuangan yang sesuai SAK EMKM dan strategi yang tepat dalam pengembangan usaha.

2. Metode Pemecahan Masalah

Tahapan ini dilakukan tim pengabdian menentukan Focus Group Discussion (FGD). UMKM mengalami keterbatasan pengetahuan dan pemahaman penyusunan laporan keuangan yang sesuai SAK EMKM dan perlunya strategi yang tepat dalam memasarkan produk. Metode yang tepat bagi UMKM adalah dengan pelatihan dan pendampingan pasca pelatihan yang dilaksanakan tim pengabdian.

3. Pelaksanaan Pengabdian

Pelaksanaan kegiatan dilakukan dengan metode ceramah dan praktik. Metode ceramah dan praktik akan dilanjutkan dengan sesi diskusi dan tanya jawab dengan pelaksanaan UMKM.

4. Review dan Evaluasi

Tahapan ini digunakan dengan tujuan untuk me-review dan mengevaluasi kegiatan yang telah dilaksanakan apakah sesuai dengan capaian yang direncanakan tim pengabdian atau tidak.

\section{Hasil dan Pembahasan}

Sebelum melakukan kegiatan pelatihan penyusunan laporan keuangan UMKM, di Kampung PIA Kecamatan Gempol masih menggunakan atau masih melakukan pencatatan secara manual yang belum memenuhi standar penyusunan laporan keuangan (SAK-EMKM). Adapun laporan keuangan tersebut dapat dilihat di bawah ini.

Tabel 1. Buku Kas

\begin{tabular}{|c|c|c|c|c|}
\hline Tanggal & Keterangan & \multicolumn{3}{|c|}{ Jumlah } \\
\hline & & Penerimaan & Pengeluaran & Sisa \\
\hline & & & & \\
\hline & & & & \\
\hline & & & & \\
\hline & & & & \\
\hline & & & & \\
\hline & & & & \\
\hline & & & & \\
\hline
\end{tabular}


Berdasarkan SAK EMKM, komponen laporan keuangan untuk entitas, mikro, kecil, dan menengah terdiri dari laporan posisi keuangan, laporan laba rugi, dan catatan atas laporan keuangan. Laporan keuangan merupakan hasil akhir dari aktivitas akuntansi. Laporan ini mengikhtisarkan data transaksi dalam bentuk yang berguna bagi pengambilan keputusan. Berdasarkan Undang-Undang No. 20 Tahun 2008 tentang Usaha, Mikro, Kecil, dan Menengah, usaha mikro adalah usaha produktif milik orang perorangan atau badan usaha perorangan yang memenuhi kriteria usaha mikro. Hasil wawancara kepada pemilik Pelaku UMKM menunjukkan bahwa pemahaman dalam penyusunan laporan keuangan tentang SAK EMKM masih rendah, dikarenakan kurangnya sosialisasi terkait dengan SAK EMKM.

Tabel 2. Kerangka Konsep Laporan Posisi Keuangan berdasarkan SAK EMKM

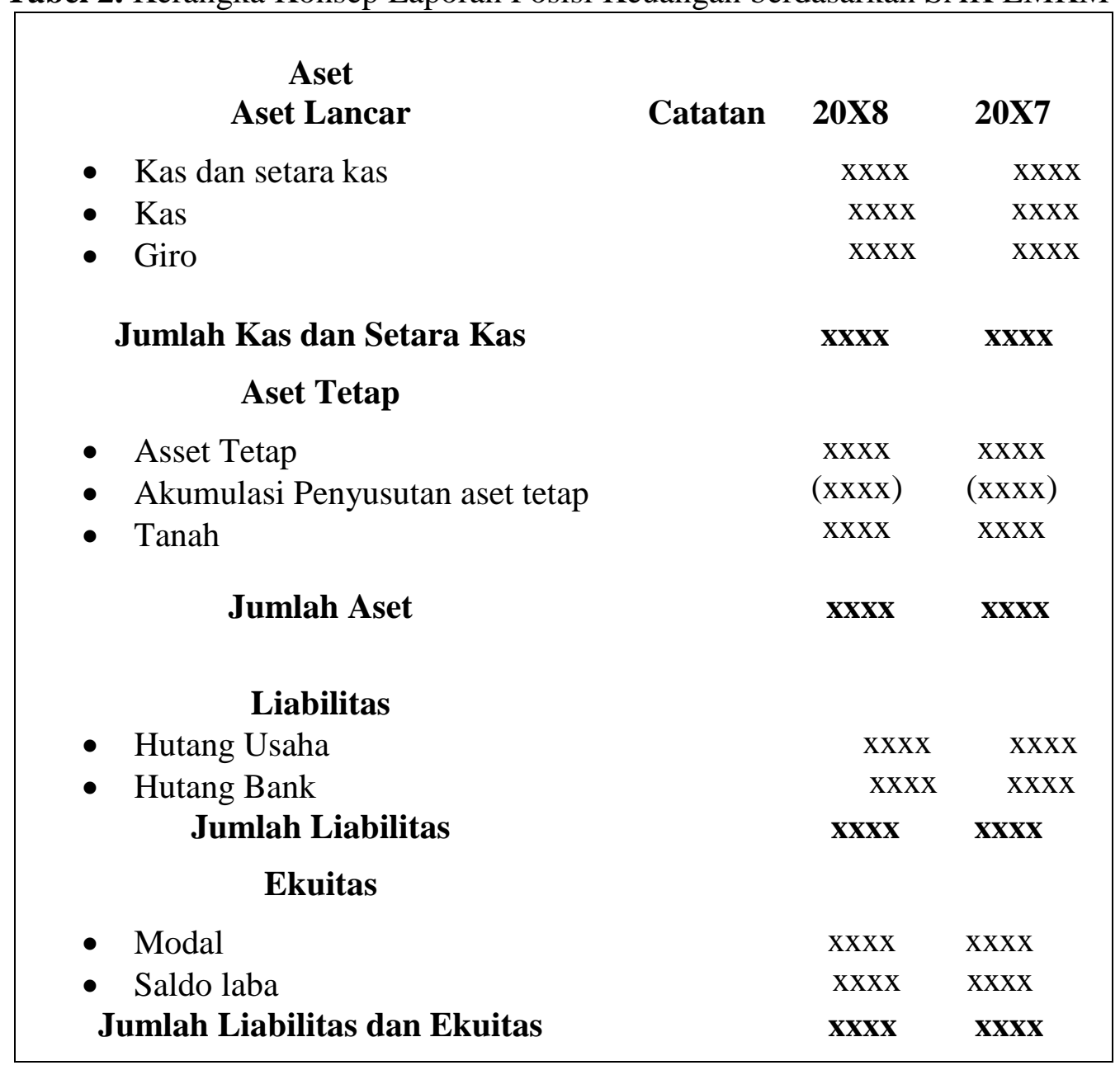

Dalam SAK EMKM (2016:3), aset adalah sumber daya yang dikuasai oleh entitas sebagai akibat dari peristiwa masa lalu dan yang dari mana manfaat ekonomi di masa depan diharapkan akan diperoleh oleh entitas. Liabilitas adalah kewajiban kini entitas yang timbul dari masa lalu, yang penyelesaiannya mengakibatkan arus kas keluar dari sumber daya entitas yang mengandung manfaat ekonomi. Ekuitas adalah hak residual atas aset entitas setelah dikurangi seluruh liabilitas. 
Tabel 3. Kerangka Konsep Laporan Laba Rugi Berdasarkan SAK EMKM

\begin{tabular}{|l|c|c|}
\hline Entitas & & \\
\hline Laporan laba rugi & & \\
\hline Untuk tahun yang berakhir 31 desember xxxx & & \\
\hline Pendapatan & 20xx & 20xx \\
\hline $\begin{array}{l}\bullet \quad \text { Pendapatan usaha } \\
\text { Pendapatan lain-lain }\end{array}$ & $\mathrm{XXXX}$ & $\mathrm{XXXX}$ \\
$\begin{array}{l}\text { Jumlah pendapatan } \\
\text { Beban Beban usaha }\end{array}$ & $\mathrm{XXXX}$ \\
\hline Beban lain-lain & $\mathrm{XXXX}$ & $\mathrm{XXXX}$ \\
\hline $\begin{array}{l}\text { Lumlah beban } \\
\bullet \quad \text { Beban pajak penghasilan }\end{array}$ & $\mathrm{XXXX}$ & $\mathrm{XXXX}$ \\
\hline Laba rugi setelah pajak penghasilan & $\mathrm{XXXX}$ & $\mathrm{XXXX}$ \\
\hline
\end{tabular}

Berdasarkan SAK EMKM (2016:4), pendapatan adalah penghasilan yang timbul dalam pelaksanaan aktivitas entitas yang normal, yang dikenal dengan berbagai sebutan, misalnya: penjualan, imbalan, bunga, dividen, royalti, dan sewa. Beban mencakup beban yang timbul dalam pelaksanaan aktivitas entitas yang normal meliputi, misalnya, beban pokok penjualan, upah, dan penyusutan. Namun, untuk perusahaan manufaktur menggunakan laporan harga pokok produksi yang digunakan sebagai informasi mengenai biaya-biaya dalam melakukan proses produksi.

Selain perbaikan sistem akuntansi UMKM yang sesuai dengan SAK EMKM, pengabdian memberikan materi analisis SWOT guna pengembangan usaha.

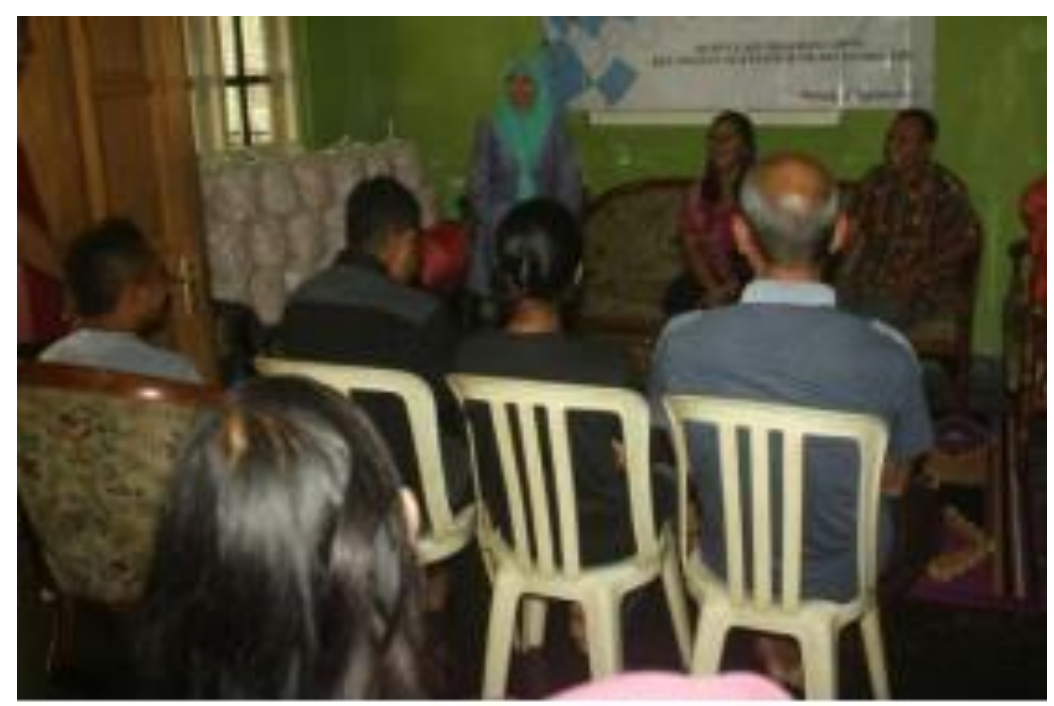

Gambar 2. Pelaksanaan Pelatihan Akuntansi dan Strategi Pemasaran 


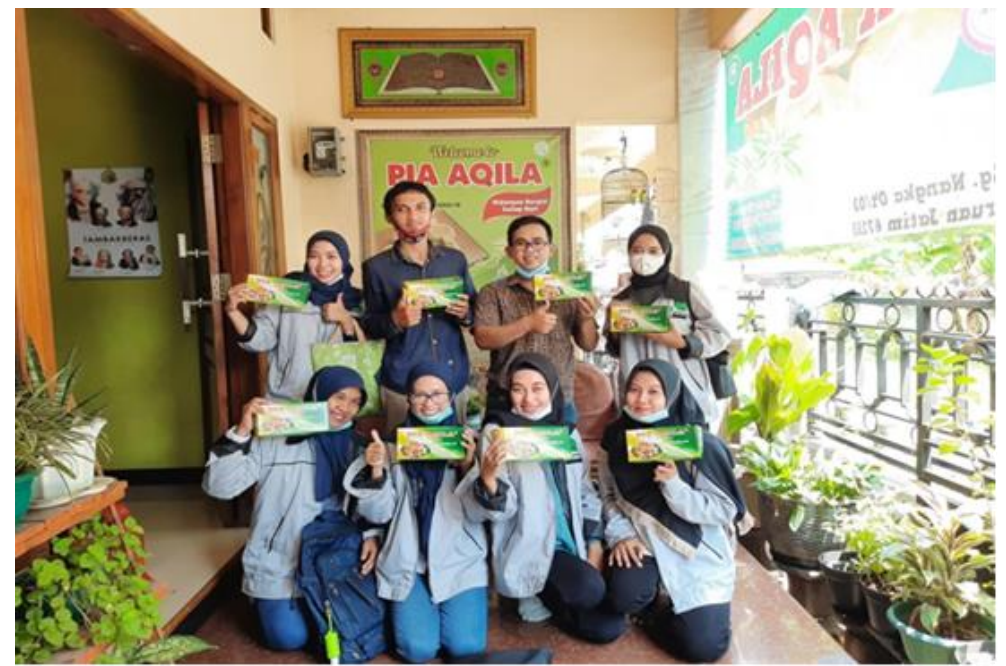

Gambar 3. Produk Pia Aqila dengan kemasan sebagai strategi pemasaran

\section{Kesimpulan}

\section{Kesimpulan dan Saran}

Pengetahuan dan pemahaman dalam menyusun laporan keuangan berdasarkan standar akuntansi keuangan (SAK-EMKM) menjadi meningkat dan keterampilan UMKM dalam menyusun laporan keuangan berdasarkan standar akuntansi keuangan (SAK-EMKM) semakin meningkat dan memahami cara strategi pemasaran guna peningkatan pendapatan UMKM.

\section{Saran}

Mengingat besarnya manfaat kegiatan pengabdian pada masyarakat ini, maka selanjutnya perlu 1) mengadakan sosialisasi dan pelatihan serupa pada UMKM di desa yang lain, dengan materi yang sama, dan 2) adanya kesinambungan program pasca kegiatan pengabdian ini sehingga para pelaku UMKM benar-benar mempraktikkan keterampilan dalam menyusun laporan keuangan sesuai dengan standar akuntansi keuangan (SAKEMKM) dan strategi pemasaran.

\section{Daftar Pustaka}

Ikatan Akuntan Indonesia. (2016). Standar Akuntansi Keuangan Entitas Mikro Kecil dan

Menengah. Dewan Standar Akuntansi Keuangan Indonesia.

Sadhana, N.B. (2013). Analisis Peranan Usaha Kecil Dan Menengah Terhadap Penyerapan

Tenaga Kerja Di Kota Malang. Jurnal Ilmiah Mahasiswa FEB, 1(2).

Saputro, O.D., \& Susilo, H. (2016). Pemberdayaan Masyarakat Melalui Usaha Kecil dan

Menengash (UKM) Studi Kasus di Sentra Industri Tepung Tapioka Desa Pogalan,

Kecamatan Pogalan, Kabupaten Trenggalek. J+PLUS UNESA, 5(1).

Tambunan, T. (2012). Usaha mikro kecil dan menengah di Indonesia : Isu-isu penting.

LP3ES.

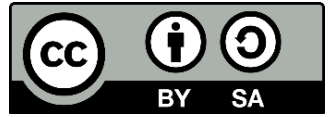

(C) 2021 oleh penulis. Pemegang Lisensi JPM, Indonesia. Artikel ini merupakan artikel akses terbuka yang didistribusikan di bawah syarat dan ketentuan Lisensi Atribusi Creative Commons (CC BY-SA) 